\title{
Práticas Educativas no Museo Histórico Nacional da Argentina: exposição de memórias e construção de histórias
} Educational Practices at the Museo Histórico Nacional of Argentina: Exhibiting Memoires and Building Histories

Carmem Zeli Gil ${ }^{\star}$

\section{REsumo}

$\mathrm{O}$ artigo tem como foco o trabalho educativo do Museo Histórico Nacional da Argentina (MHN), desenvolvido com escolas, durante o ano de 2015. Nesse sentido, procura-se refletir sobre as escolhas do museu para efetivar sua proposta educativa no desafio entre expor memórias e instigar a produção de histórias. Observações, entrevistas e aplicação de um questionário com professores que acompanhavam seus alunos ao MHN são os documentos examinados para as reflexões aqui propostas. Ao final, as considerações apresentadas buscam caracterizar como o debate sobre museus e escola tem se renovado nas últimas décadas com os pressupostos teóricos da museologia e da educação de cunho mais social. O artigo é fruto dos estudos de pós-doutoramento desenvolvidos na Facultad de Filosofia y Letras da Universidad de Buenos Aires, entre março e novembro de 2015.

Palavras-chave: museu; ensino de história; escola.

\section{Abstract}

The article focuses on the educational work at the Museo Histórico Nacional (MHN) of Argentina, developed with schools during the year of 2015. In this sense, we analyze the choices that the Museum staff takes in order to accomplish its educational goals amid the challenge in exhibiting memoirs or inciting storytelling. The proposed reflection is based on the review of observations, interviews and a questionnaire with some of the teachers who took their students to the MHN. The findings attempt to distinguish how much the debate about museums and schools has been renewed in the last decades, under the theoretical developments on museology and a more socially driven education. The article is the result of postdoctoral studies developed at the Facultad de Filosofía y Letras of the Universidad de Buenos Aires, between March and November 2015.

Keywords: museum; history teaching; school.

\footnotetext{
* Universidade Federal do Rio Grande do Sul (UFRGS), Porto Alegre, RS, Brasil. carmemz.gil@ gmail.com
} 


\section{Salas e Aulas i - O contexto}

Te costó cruzar los Andes?

A pergunta em epígrafe é de uma menina de 5 anos que, no dia 9 de outubro de 2015, visitou o Museo Histórico Nacional da Argentina (MHN) com sua professora e os colegas de uma turma de ensino pré-escolar (que, na Argentina, abrange as crianças dos 45 dias aos 5 anos de idade). Essa pergunta foi dirigida a San Martín na sessão do MHN Charlas con el General San Martín, uma proposta na qual os visitantes mantêm um diálogo com um retrato do Libertador.

Passei dias pensando nessa pergunta, porque se tratava de uma criança de 5 anos a questionar não o feito do personagem, amplamente divulgado na sociedade argentina, mas a pessoa supostamente representada de San Martín. Enquanto a lógica adulta fala do herói, a criança busca saber da pessoa que foi o "herói". Além disso, havia uma complexidade na pergunta que demandava saber o que era a Cordilheira dos Andes, quem era San Martín e qual tinha sido seu grande feito. A pergunta possibilita formular algumas hipóteses: indica a significação de uma memória institucionalizada, amplamente divulgada? Pode ser, até porque a nação existe unicamente porque um grupo de pessoas que acredita nela e compartilha crenças sobre o passado. Situa a competência do educador do museu informando sobre os feitos de San Martín? Anuncia o trabalho da escola permitindo o desenvolvimento da noção de espaço? Trata-se de perguntas com respostas provisórias que possibilitam pensar escola e museu como instituições inter-relacionadas em seus fazeres. Certamente a pergunta dessa criança foi possível em razão da continuidade do trabalho pedagógico desenvolvido em ambas as instituições. Também é certo haver uma memória histórica construída em torno do mito de San Martín, uma construção social e histórica que envolve escola, Estado, meios de comunicação que criam/divulgam artefatos sociais - crenças, símbolos, compromissos -, que cimentam a nacionalidade. Por isso a memória é tão importante para as nações.

O exercício de pensamento que realizei, com base nessa e em outras perguntas que os alunos fizeram a San Martín, me instigou a pensar que o museu não é instrumento complementar para a escola, e que os escolares não são simplesmente um público para o qual o museu desenvolve ações educativas ou 
difusão cultural. Tal propósito foi válido para um tempo em que o papel dos museus era o de auxiliar a escola no desenvolvimento de uma educação para a consciência patriótica. Quero crer que hoje as motivações são outras e, portanto, entre escola e museu existe continuidade nas práticas de formação: ir ao museu para continuar desenvolvendo temas, conteúdos, ideias, conceitos, valores. Nas salas de exposição os alunos realizam atividades de leitura, escrita, observação de objetos, discussão, reflexão e interação, semelhantes às que fazem nas aulas. Indiscutivelmente há diferenças na função e nos tempos dessas instituições, e não necessariamente tais diferenças têm relação com a divisão tão comum entre educação formal e informal, até porque o que não tem forma não existe. Que relevância tem essa divisão se pensarmos no quanto de formalidade há em algumas atividades nos museus e o quanto de informalidade há nas atividades das escolas? Reconhecendo as diferenças entre as instituições, quero pensar numa relação que se estabelece pela continuidade do aprender. A pergunta em epígrafe tem, certamente, relação com o que essa criança ouviu da professora na escola, da educadora no museu, da família em sua casa, nos episódios da Zamba na TV argentina, de forma a estruturar uma compreensão sobre San Martín que permitiu a sua construção.

Importante reconhecer que, desde a Declaração da Mesa de Santiago de Chile, em 1972, que propôs a reflexão e a crítica permanente sobre a importância social dos museus, houve avanços na relação entre museu e escola. Há pouco mais de 20 anos não havia possibilidade de um setor educativo se anunciar como tal no âmbito dos museus. A grande maioria das escolas, quando levava seus alunos ao museu, solicitava a cópia de todos os textos das legendas dos objetos. Hoje essas duas instituições compartilham inúmeros outros sentidos, apesar de suas estruturas rígidas e com múltiplas funções. Para a escola, ir ao museu demanda autorizações de pais e da Secretaria de Educação, recursos financeiros, reorganização de horários, deslocamentos de funcionários e professores, preparo de listas de alunos etc., uma empreitada árdua. Nos museus, a epopeia não é menor: poucos recursos, equipe reduzida, invisibilidade do setor educativo, conflito entre os setores educativo e de conservação. Enfim, muitos desafios e tensões, embora se reconheçam avanços em ambos os espaços.

O propósito aqui é construir breves reflexões sobre a proposta educativa do MHN: o que o museu oferece às escolas? O que a escola faz com o que o 
museu oferece? E, com isso, pensar mais sobre a relação museu-escola. Os dados resultaram de observações e registros em um diário de campo, análise de material produzido pelo Departamento de Ação Educativa e Extensão Cultural e um questionário respondido pelos professores durante a visita. Para tanto, de maio a outubro de 2015 passei a observar o trabalho de mediação, as atividades com as turmas de alunos, a programação nos finais de semana e, ao mesmo tempo, pude conversar individualmente com a equipe educativa; o questionário foi aplicado em outubro de 2015.

Devo dizer que, nesse processo de estudo de museus e escolas em Buenos Aires, um dos principais documentos de investigação foi a própria investigadora, na condição de quem observa, escuta, interroga e registra as opiniões para compor o que ora apresento. Isso não significa, no entanto, que a reflexividade metodológica seja mero esforço de autoanálise. O esforço se deu no sentido de construir um diálogo entre o que sabia e o que observava. Por que, em determinados momentos, algumas coisas eram mais bem percebidas, e outras passavam a ter mais sentido em outros momentos? Como as novas aprendizagens questionavam algumas certezas sobre escola e museus? Vigiava as interpretações buscando fugir das pré-noções e das verdades que fecham o campo de reflexão. A atitude foi de expectativa e abertura ao que poderia ser, até porque estava em terreno alheio/desconhecido.

Para desenvolver a reflexão, organizei o texto em três partes, após uma breve introdução: a primeira apresenta o MHN; a segunda, as atividades que o museu desenvolve com as escolas; e a terceira parte apresenta o que emergiu nas respostas dos professores. Por fim, reflexões para continuar pensando.

\section{Salas e Aulas it - O Museo Histórico Nacional}

O Museo Histórico Nacional ocupa um prédio italiano, localizado na rua Defensa, bairro de San Telmo, junto ao Parque Lezama. Situado numa barranca, o parque tem mirantes que, no passado, davam para o rio e, hoje, dão para a feira que ocorre aos domingos na avenida Martín García. Nos finais de semana, o museu abre um grande portão e se torna uma continuidade do Parque Lezama, oferecendo shows e atividades esportivas no seu jardim. Atrai, portanto, pessoas de todas as idades: pais com carrinhos de bebê circulam entre canhões e estátuas; namorados trocam afetos nos jardins 
do templo da nação; crianças brincam no entorno do jardim; um comércio de artesanatos marca outros usos para o monumento a Pedro de Mendoza, provável fundador da cidade. Enfim, sem dúvida, o museu torna-se um espaço de sociabilidades diversas.

Quanto à sua localização, o MHN não está em um lugar qualquer, porque foi nesse local que, provavelmente, Pedro de Mendoza fundou Buenos Aires, em fevereiro de 1536. Portanto, o museu se insere em um contexto histórico que remete a um fato considerado fundacional, obviamente não do ponto de vista dos povos originários. Não por acaso, a primeira frase que abre o texto de apresentação do MHN, no site do Ministério da Cultura, é "En busca de una Nación”. O texto faz referência às mudanças sociais e econômicas do país e à necessidade de construir um sentimento de nacionalidade, apelando a "un acervo común de tradiciones y a una historia compartida. [...] El Museo fue concebido como el Panteón de la Patria donde se guardaban y veneraban las reliquias de los próceres de la Revolución de Mayo y las guerras de la independencia” (Museo Histórico Nacional, 2019, online).

A segunda parte desse mesmo site apresenta "La renovación del Museo Histórico Nacional", destacando que "el territorio nacional, hace no menos de 10.000 años [...] Se trata de proponer un museo dinámico que ofrezca distintas visiones del pasado, a través de un diálogo amplio capaz de manifestar las diversas maneras de ser argentino" (Museo Histórico Nacional, 2019, online).

O texto de apresentação, no site do Ministério da Cultura, de certa forma sintetiza o que vive a instituição hoje: a tensão entre as razões para as quais foi criada, o que efetivamente é e o que pretende ser, definindo o que e como se mostrar. Por exemplo, o visitante que chega ao museu é recebido por dois canhões de bronze de 1776, expostos na escadaria que dá acesso ao pátio, próximo à porta de entrada (Figura 1). No entanto, historiadores anunciam que houve mudanças na expografia do MHN buscando romper com esse caráter bélico: "hay que señalar que se dejaron de lado aspectos bélicos que anteriores muestras del Museo habían enfatizado, como las invasiones inglesas, la guerra contra Brasil o Paraguay e incluso el más reciente conflicto de Malvinas" (Bohoslavsky; Oleaga; Liscia, 2010, p. 3). 
Figura 1 - Entrada do MHN

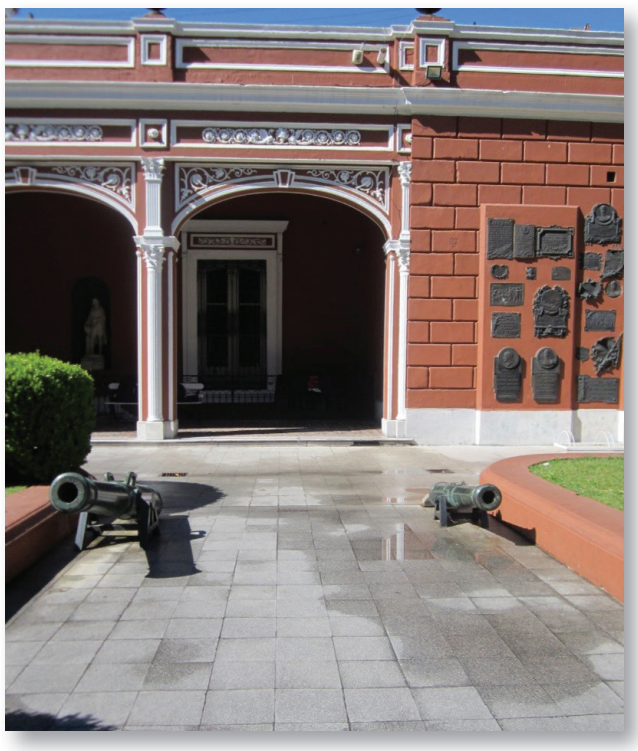

Fonte: Acervo da autora.

Trata-se de um detalhe? Talvez, mas os museus diferem exatamente pelo olhar que propõem aos objetos. Cada museu produz argumentos e, portanto, educa ao expor os objetos de uma forma e não de outra.

Ao entrar no saguão, um texto apresenta o museu ao visitante com ênfase em dois momentos: o primeiro é o da sua inauguração, em 15 de fevereiro de 1891, sob direção de Adolfo Carranza, com o objetivo de exibir objetos referentes à Revolução de Maio e à Guerra da Independência, promovendo uma educação patriótica sob o olhar de sua época. Constituiu assim, segundo o texto de apresentação, um relato centralista, portenho e aristocrático. No segundo momento, o texto destaca o compromisso atual do Museo Histórico Nacional, que acompanha a renovação historiográfica e incorpora novos atores: povos originários, negros, mulheres e o protagonismo das províncias, respeitando a diversidade social e cultural da Argentina.

A narrativa sobre o passado, apresentada pelo museu, está organizada em 12 exposições permanentes e um espaço com jogos multimídia. Três dessas exposições foram inauguradas em 2015: "Sala del sable corvo de San Martín”, "Pueblos originarios" e "Autonomías provinciales y época federal", além de 
mais nove espaços: "Presidencias históricas (1853-1910)", "Conquista y Orden Colonial”, "Revolución de Mayo y Guerra de la Independencia”, "Símbolos Patrios", "Sociedad Porteña en 1810", "Las armas del pueblo", "San Martín de puño y letra”, "Dormitorio del general José de San Martín” e a "reserva visitable". Em julho de 2014 foi inaugurada também a sala interativa, para as crianças, com seis videojogos sobre história da Argentina.

De certa forma, para o estrangeiro que visita Buenos Aires o MHN permite conhecer quem foram, afinal, os próceres que dão nome às principais avenidas, praças e parques portenhos. Estão todos lá. Se o visitante se dirigir para a direita encontrará a sala "San Martín de puño y letra", destinada a mostrar aspectos da vida política do líder. Lá estão vitrines com objetos pessoais do general, como o catre que usou na campanha libertadora, o poncho presenteado pelos índios Mapuche, medalhas outorgadas a ele, objetos usados na Campanha do Chile e do Peru, uniforme de gala e pinturas de uma época posterior, objetos bastante vinculados com a construção do líder patriótico. Tudo isso tramado nas transcrições ampliadas de cartas e textos de San Martín. Separada por um vidro encontra-se a reprodução do quarto de San Martín, em sua casa em Bologne-sur-Mer (França), e até sua cama, onde, segundo os mediadores, ele passou os últimos momentos de vida. Na entrada da sala sanmartiniana está um banner que destaca seu interesse pela leitura, junto a uma vitrine com livros. O texto do banner traz palavras do líder na ocasião em que inaugurou a Biblioteca Nacional de Lima, em 17 de setembro de 1822, fazendo emergir mais a pessoa do que o herói. Importante destacar que essa sala não faz referência a nenhum estudo sobre San Martín, evidenciando uma distância entre a historiografia e a expografia, que coloca ênfase em escritos do próprio San Martín, embora sem contextualizá-lo nas representações construídas sobre ele. A narrativa nas salas de San Martín reafirma o líder marcado pela simplicidade, enfermidade e capacidade de grandes bravuras em nome da liberdade. Ao final da sala, um corredor de armas com pequenos focos de luzes, que iluminam espadas e sabres ao som de uma música, conduz o visitante até o acesso a outro ambiente, inaugurado em maio de 2015, onde dois granadeiros guardam o "Sable corvo" do general. A imponência dos vitrais, no teto, confere ao pequeno ambiente um ar de templo (Figura 2), no qual se admiram armas e homens públicos, embora o destaque seja para o sabre que acompanhou San Martín em suas batalhas. 
Figura 2 - Sala Sable de San Martín

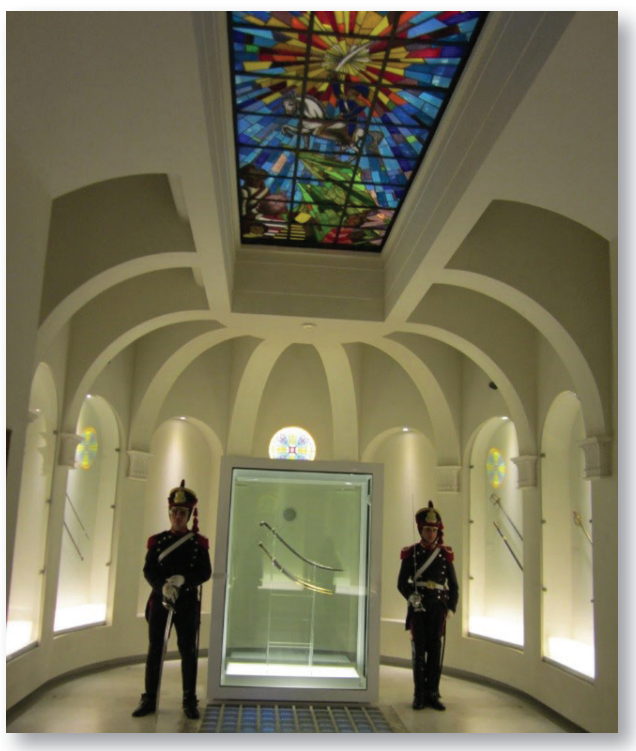

Fonte: Acervo da autora.

Se o visitante se dirigir à esquerda, encontrará um jogo interativo intitulado Charla con el General San Martín, realizado a partir do daguerreótipo de Robert Bingham, único registro fotográfico do líder. Em uma conversa informal, o público pode fazer perguntas até 1848, ano em que foi realizado o daguerreótipo. Registrei um conjunto de perguntas durante as observações de escolas na visita ao museu. Cito algumas: "Por que você libertou o Chile e o Peru?"; "Qual foi a primeira vez que te deram o comando?"; "Com que idade você ingressou no Exército?”; "Como cruzou os Andes?"; "Você gostava da sua vida quando estava nas batalhas?”; “Gostava da vida?”; "Por que quis ser militar?"; “O que sentiu na guerra?”; “Qual foi a batalha mais difícil?”; “Como era o seu cavalo?"; "Havia mulheres no Exército?”; "Por que não ficou na Argentina?"; "Onde você estava quando sua esposa morreu?"; "Qual foi seu melhor amigo na escola?"; "De que música você gosta?"; "Havia esporte na sua época?"; "Sua cama não é muito pequena?”; “Tem alguma enfermidade?”; "O que você gostava de comer?"; "Se estivesse neste governo, o que faria?"; "Por que você está em um quadro?”; "Você é de verdade?". 
As perguntas evidenciam curiosidade com a vida e a obra do líder, às vezes relacionada com informações recebidas no trajeto formado pelas salas que tematizam San Martín; em outras se percebem aproximações com os conceitos desenvolvidos na escola ou em outros espaços. E, ainda, outro conjunto de perguntas diz respeito à pessoa do líder e seu modo de vida. Algumas perguntas se repetem independentemente da idade de quem as formula, e têm relação com as ideias que circulam em torno do mito.

As respostas baseiam-se em cartas e outras evidências históricas, e são improvisadas por um ator que coordena o movimento da imagem de San Martín e o som da sua voz. O ator, de 63 anos, é um advogado, docente, e desde criança estuda a vida de San Martín. Contou-me que as perguntas das crianças estão relacionadas ao mito criado em torno da figura do líder. Pintores exaltam San Martín em um cavalo branco, e as perguntas seguem nessa direção. Muitos querem saber sobre o seu cavalo, a enfermidade, a travessia dos Andes, e sobre a sua vida privada. Trata-se de uma sessão muito atrativa para todas as pessoas que observei no museu.

Importante lembrar que, para a História, "falar com San Martín” pode levar as crianças a construir uma ideia do passado como algo que pode ser acessado, mas também amplia o espaço da ficção. De qualquer forma, independentemente da escolha do visitante, o percurso do MHN começa e termina em San Martín.

Continuando, o visitante pode ainda se dirigir ao centro do hall de entrada e escolher entre o auditório, com quatro grandes pinturas celebrativas, ou caminhar por um corredor que situa parte da história de criação do MHN. A exposição - Adolfo P. Carranza, Una vida para la Historia - é uma homenagem ao fundador e primeiro diretor do museu. Destaca a difícil empreitada de Adolfo Carranza para formar um museu de história em Buenos Aires em fins do século XIX, as sedes anteriores do museu, a composição da Coleção e uma linha de tempo com momentos marcantes da instituição, desde a sua fundação até a morte de Carranza, em 1914 (Figura 3). Interessante observar que uma foto ampliada tem destaque na exposição e enfatiza, embora isso não seja mencionado nos textos da exposição, a ideia de colecionismo que vigorava naquele século e que influenciou a forma de expor os objetos. De maneira geral, o colecionismo era o gesto de arranjar, no tempo e no espaço, objetos com características históricas e artísticas. Para a escola ou a quem interessar, a exposição 
tem a potencialidade para discutir o conceito de museu em suas mudanças e permanências. E, talvez assim, situar melhor por que o primeiro diretor fez determinadas escolhas na apresentação dos objetos.

Figura 3 - Foto ampliada destacando um detalhe da forma como o museu apresentava os objetos

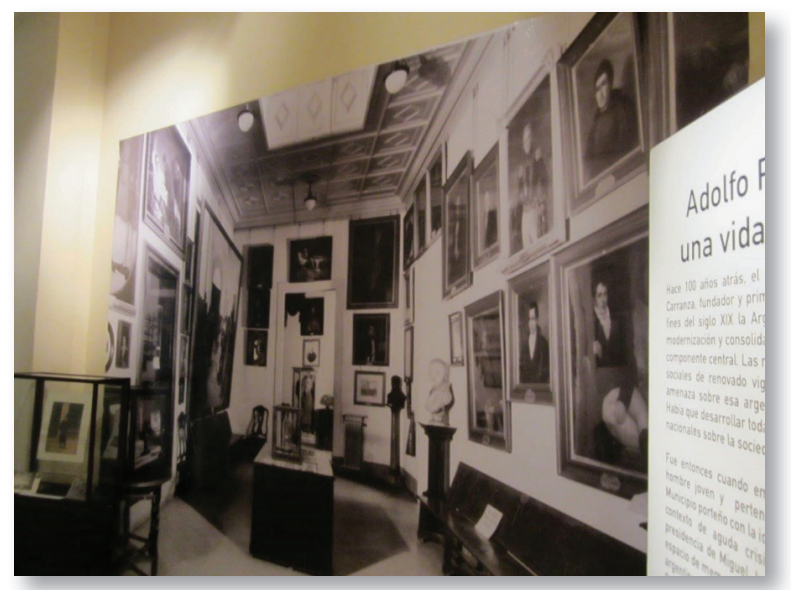

Fonte: Acervo da autora.

Uma investigação recente sobre o MHN é a de Carolina Carman, publicada em 2013, intitulada Los orígenes del Museo Histórico Nacional, na qual explicita as estratégias políticas e econômicas de uma equipe da alta sociedade portenha para criar o museu. A autora defende que o museu surgiu na fronteira entre o Estado e o âmbito privado, a partir da vontade de um grupo de homens que levaram adiante a tarefa de montar "un dispositivo capaz de inculcar una identidad nacional en la sociedad, al mismo tiempo que esa identidad - directamente asociada a la pregunta por la argentinidad - estaba siendo calurosamente discutida" (Carman, 2013, p. 20).

Um decreto do intendente municipal da cidade de Buenos Aires, em 24 de maio de 1889, nomeava a Comissão encarregada de criar o museu e apresentava os motivos que impulsionaram a criação de um museu nacional:

Siendo necesario, para obtener tales resultados, que los objetos, mencionados se concentren, coloquen y guarden convenientemente en un museo nacional y no 
existiendo en poder de las autoridades más que limitado número de ellos, estando algunos en poder de particulares y encontrándose dispersos en todo el territorio nacional. (Buenos Aires, 1889)

A maior parte das coleções do MHN foi constituída entre 1890 e 1914, com doações de órgãos públicos ou colecionistas empenhados na afirmação de uma memória celebrativa. O total de itens das coleções, hoje, é 47.034, segundo dados do setor de patrimônio do museu. Seguindo a prática do colecionismo, a condição para que os objetos fossem aceitos no acervo do MHN era seu vínculo com homens públicos e com os acontecimentos destacados do passado nacional. Esse movimento, de uma parte da elite portenha, não foi isolado. No contexto internacional, na mesma época, inauguravam-se museus em diferentes capitais do mundo, ligados à Memória Nacional. Os grandes museus europeus criados nos séculos XVIII e XIX serviam de modelo. Ulpiano Bezerra de Meneses (1994, p. 65) escreve que "a fragmentação dos museus em especialidades tem também sua história que aponta para o século XVIII, e o desenvolvimento dos museus históricos aponta para o século XIX, associado ao surgimento das nacionalidades". Trata-se de instituir uma visibilidade do passado a serviço de um projeto de futuro que difere, por isso, das formas de visualização do passado praticadas pelo colecionismo.

Na mesma linha, Brefe (2005, p. 39) explica o surgimento dos museus de história no século XIX, como uma instituição legitimadora de uma memória nacional, pois, "não apenas na França, mas em toda a Europa, foram criados museus voltados para a representação da história nacional que justificassem a nação como unidade". Próximo a essa ideia está o que Ulpiano Meneses (1994) diz, citando Hooper-Greenhill, chamando o museu como teatro da memória, onde coleções e os objetos tinham o propósito de recriar simbolicamente a ordem do mundo renascentista. Apelava-se para a matriz sensorial, que facilita a rememoração e tem, portanto, notável impacto pedagógico. Esse modelo parece dizer muito ainda sobre as funções dos museus de história.

Salas e Aulas iII - o mhn e as escolas

O que o MHN oferece às escolas de Buenos Aires? Como a nova fase do museu, anunciada nos textos de apresentação, influencia a sua relação com a 
escola? Até que ponto a proposta educativa do museu contribui para o projeto atual de educação na Argentina, com ênfase na defesa dos direitos humanos?

Os museus, surgidos no decorrer do século XIX, tiveram como modelo os museus de História Natural e preocuparam-se com a dimensão pedagógica, buscando receber os estudantes para as "lições de coisas" (Barbuy, 2002). As tendências pedagógicas europeias do século XIX recomendavam ensinar ciências com os objetos naturais e industriais: lâminas, mapas murais, coleções mineralógicas, espécies embalsamadas, esqueletos e aparatos para demonstrações científicas, entre outros dispositivos. Nesse contexto, os museus de História educavam para a formação da consciência nacional, ao passo que os de Ciências Naturais ocupavam-se da exploração da natureza. O certo é que a função educativa dos museus é inerente à sua formação, embora nem sempre o público seja a sua preocupação central. No MHN, Adolfo Carranza, além de reunir objetos, montar exposições e editar documentos históricos, empenhou-se também em estabelecer relações com o público escolar. Dois dias após a sua inauguração, o diretor do museu escreveu às autoridades educativas da Capital Federal solicitando que elas enviassem seus alunos e professores para conhecer o novo museu, conforme afirma Carolina Carman:

y como al fundarlo se ha tenido en vista principalmente que él sirva para inculcar a los niños el amor a nuestros próceres y el conocimiento del pasado por medio de los retratos, objetos, etc. que allí se reúnen, creo de mi deber ofrecer al señor Presidente la facilidad de que los alumnos de las escuelas que están bajo su dirección asistiesen al local ya sea en los días indicados para el público o en los días que solo se abren las oficinas. (Carman, 2013, p. 65-66)

Carman (2013) indica diversos outros momentos em que o diretor enviava correspondências às autoridades, convidando professores e alunos a visitarem suas exposições. Tal fato está em consonância com a perspectiva de patrimônio como uma pedagogia pública que tomava, na sua maioria, obras de arte e objetos pertencentes a homens públicos para ensinar às novas gerações a identidade imaginada. Portanto, os museus nascem com esse sentido educativo de transmissão de valores, de modo a contribuir na construção da ideia de nação. No caso do MHN, percebe-se a preocupação com um público em especial: o escolar. Ou seja, tratava-se de destacar as conexões entre museu e escola desde a fundação do MHN. 
Em 2015, o MHN tinha um Departamento de Accion Educativa y Extensión Cultural constituído de uma equipe de seis pessoas: três historiadores, um guia de turismo, um antropólogo e um museólogo. O grupo realiza atividades específicas que envolvem coordenação de visitas guiadas, acompanhamento estatístico de público, realização de trajetórias por nível de ensino, mediação com visitas guiadas, tradicionais e temáticas, e visitas da Ronda Cultural. ${ }^{1}$ Em junho de 2015, no fôlder do Departamento do MNH, constava um conjunto de atividades oferecidas às escolas, por nível de ensino, com ênfase na observação e descrição de objetos do museu. Em alguma medida, as atividades têm o mérito de romper com a visita panorâmica, em que o aluno ouve informações do mediador e copia legendas dos objetos. Como insiste Ulpiano Meneses (1994), a maior contribuição dos museus é a educação pelo objeto, que é diferente de "falar sobre os objetos" ou usar essa materialidade do museu para ilustrar conteúdos, recorrente em determinadas práticas de lazer como jogo da memória, quebra-cabeça, caça-palavra, cruzadinha, liga-pontos, folha para colorir etc. Ao olharmos para os objetos, no museu, os vemos como objetos históricos que perderam o sentido para o qual foram criados e adquiriram o potencial de evocador do passado, sendo importante, então, colocá-los em situação pedagógica que permita a reflexão sobre o visível do tempo presente e o invisível do passado.

Importante destacar que as atividades são destinadas, em grande parte, aos alunos da escola Primária (ou Fundamental, no Brasil) e são, portanto, as crianças que mais circulam no MHN, com seus professores, de forma que a especificidade desse museu se aproxima mais dos conteúdos desse nível escolar. Uma das atividades mais solicitadas pelas escolas é a "Búsqueda del tesoro en la Sala Puño y letra y Sala Tesoros”. Apresento aqui breves comentários sobre essa atividade, também motivados pela pergunta em epígrafe.

A primeira parte da atividade consiste em uma conversa com os alunos sobre objetos públicos e sua preservação para que outras gerações possam aprender sobre o passado com tais objetos. Depois disso, cada grupo de alunos recebe uma folha com pistas de um objeto para encontrá-lo na sala San Martín. As pistas destacam características e funções dos objetos, com ênfase nos feitos de San Martín. Após a identificação dos objetos, os alunos sentam no chão, próximos à sala que reconstrói o quarto do general, para uma conversa que começa com uma rodada de perguntas: "O que é isso? Seu quarto quando era 
velho ou quando era novo? Que objetos do quarto encontraram? O que parece este quarto? Original? Cópias? Por que reconstrução do quarto? Onde morreu San Martín?". À medida que os alunos identificam os objetos do quarto, a mediadora explica sua função e alguns elementos dos modos de vida de outro tempo: "Por que a pia não tem cano? Como chegava a água? Quem levava? Quem comprava água? Por que a campainha da réplica da porta da casa era assim? Havia luz? Qual a diferença em relação às campainhas de hoje?”. Os comentários sobre os objetos recaem na rotina do líder durante seus últimos tempos de vida, a saúde precária e a relação dos objetos com a vida dos alunos, modos de vida de outros tempos e, dependendo da idade dos alunos, questões que envolvem mais a história da Argentina.

Esse é o momento pedagógico mais importante da atividade, porque os objetos não têm sentido em si, e seria ilusão buscar nos objetos o seu próprio sentido (Meneses, 1994). Forma geométrica, peso, cor, textura, dureza, técnica de fabricação, sinais de uso, indícios de sua duração, entre outros, são aspectos que podem ser encontrados no objeto, mas necessitam de suporte de informação externa ao objeto. Daí a importância, nesse caso, da conversa sobre os sentidos e as relações dos objetos, como também as formas de aquisição e a sua própria trajetória no museu. Os objetos de San Martín têm uma biografia no MHN e "para explicar essa biografia é necessário examiná-los 'em situação', nas diversas modalidades e efeitos das apropriações de que foram parte. Não se trata de recompor um cenário material, mas de entender os artefatos na interação social” (Meneses, 1994, p. 27). Nessa direção, certamente o MHN, mais do que exibindo a memória, estaria fazendo histórias.

Essa atividade, a "Búsqueda del tesoro en la Sala Puño y letra y Sala Tesoros”, é oferecida desde 2013 pelo museu e, até o final de 2015, todas as semanas havia escolas que a solicitavam. Nesse período, os objetos que faziam parte da busca ao tesouro se modificaram, alguns eram retirados da exposição, e outros, acrescentados. Em outubro de 2015, a atividade ocorria com 11 objetos: "bastón, lavabo, réplica de la puerta de San Martín en Francia, yesquero, foto en miniatura de su esposa, los cuadros El paso de los Andes y El Combate de San Lorenzo, falucho, escribanía, catre de campaña y el estribo". Segundo a mediadora, a escolha dos objetos tem relação com os diferentes materiais que os compõem, a possibilidade que o objeto têm de disparar uma história, estabelecer diferenças temporais, relacionar-se com a vida do aluno e costumes de 
épocas. Por exemplo, o catre permite conversar com os alunos sobre as condições de vida dos soldados, embora a mediadora destaque a dificuldade em realizar uma reflexão mais profunda sobre o passado, por causa da idade dos alunos $\left(4^{\circ}, 5^{\circ}\right.$ e $6^{\circ}$ grados $)$. Dificilmente se consegue ir além do comentário que problematiza a ideia de um herói que realizou grandes feitos sozinho, destacando que hoje temos outra compreensão dos processos históricos, sempre resultantes da ação de diferentes grupos, que teriam sido esquecidos pela história.

Geralmente, a atividade segue o rumo das perguntas dos alunos. Alguns querem saber como limpam os objetos, o que abre a possibilidade de a mediadora conversar sobre a conservação e os diferentes profissionais que, embora não sejam vistos pelos alunos, trabalham no museu para que os objetos possam continuar existindo e sendo conhecidos por mais pessoas. Outros grupos, em contato com os objetos, querem saber mais sobre a vida cotidiana: "Como faziam isso? Como resolviam as dificuldades? Do que gostavam?”.

Cabe destacar que o roteiro da atividade não implica uma longa introdução sobre a sala San Martín, o que, geralmente, cansa os alunos e conduz o olhar para determinados objetos. Ao contrário, o grupo passa um bom tempo circulando, observando, conversando e tentando encontrar os objetos. Depois se desenrola a conversa a respeito dos objetos, das hipóteses e das curiosidades dos alunos. Trata-se de uma dinâmica interessante, que pressupõe a visita como uma experiência cultural e não como uma atividade em que os alunos - aqueles que não sabem - são guiados por alguém que tem o conhecimento. Ana Mae Barbosa (2008) propõe a visita comentada ou dialogada que envolva a participação dos alunos e a exploração do museu como um espaço de buscas. Para a autora, o "sentido epistemológico de uma visita de educador de museu com qualquer público tem sempre que ser o diálogo" (Barbosa, 2008, p. 30).

No próximo tópico, trato de comentar as respostas dos professores ao questionário: "O que fazem com o que o museu oferece? Que aspectos enfatizam no estudo sobre San Martín? Problematizam a narrativa que o museu oferece do passado?".

\section{Salas E AUlas IV - Os PROFessores}

O questionário foi aplicado nos meses de outubro e novembro de 2015. Ao chegar ao museu com seus alunos, o professor recebia uma folha com estas 
perguntas: 1. Por que você visita museus com os alunos? 2. A visita ao museu é relevante para os alunos? (Se sim, descreva qualquer situação que ocorreu na sala de aula ou durante a visita, na qual se verificou isso.) 3. Algum conteúdo é trabalhado com os alunos antes da visita? (Se sim, quais?) 4. Você solicita aos alunos alguma atividade após a visita? (Se sim, quais?).

Um conjunto de 31 questionários foi respondido pelos professores de escolas públicas e privadas de diferentes graus de ensino. Obviamente é necessário considerar aqui a autoridade do museu, visto que era o mediador quem solicitava ao professor responder, esclarecendo que se tratava de um estudo para compreender a relação museu-escola. Ao destacar tal questão, reduplica-se a provisoriedade das reflexões empreendidas, contextualizadas no breve exercício de uma escuta pontual, que se fez nas condições descritas acima.

$\mathrm{O}$ primeiro aspecto a destacar diz respeito à crença, do conjunto de professores que responderam ao questionário, quanto ao museu como um espaço onde os alunos aprendem. ${ }^{2}$ Durante a visita, os alunos realizam a atividade "Caça ao tesouro", na qual, ao pesquisar objetos e informações, os alunos ressignificam conhecimentos anteriores. Outra professora escreve: "Eles ficam agradavelmente surpresos e aprendem sobre fatos, anedotas históricas que, de outra forma, não fariam”. E, ainda: “É um lugar maravilhoso para a divulgação da obra sanmartiniana e a geração de amor pela pátria. Obviamente que o conteúdo dessa aprendizagem tem relação com a especificidade do museu, ou seja, aprendem "história da nação; sobre a vida de San Martín; sobre a nossa história; conteúdos dos povos originários". Para esses professores, o MHN é um lugar com conteúdo histórico, rico em cultura, que permite complementar os conteúdos; uma oportunidade para os alunos vivenciarem os conteúdos de forma prática, vivenciar fatos do passado; é um espaço motivador para conhecer a história e realizar uma experiência direta com objetos de diferentes épocas: "Sí, es significativa porque los niños puedan ampliar os conocimientos a medida que vivencian situaciones. Observar, escuchar, mirar, vivenciar los diferentes objetos, fotos, historias que transmite la guía para luego continuar trabajando en la sala".

Três respostas diferem do conjunto, afirmando ser o museu uma oportunidade para o aluno conhecer o ofício do historiador, para recuperar a importância dos objetos e dos documentos e para trabalhar conteúdos com diferentes fontes. Trata-se, talvez, de uma pista a respeito da expectativa do professor 
quando leva seus alunos ao museu para fazer as oficinas, e não a visita tradicional.

Os professores acreditam que os alunos voltam ao museu com seus familiares para novas visitas, e que não teriam essa oportunidade sem a mediação da escola. Na sala de aula, apontam que os alunos fazem referência às informações obtidas durante as atividades realizadas no museu, ampliando a compreensão dos temas estudados. A palavra mais citada nas respostas da Questão 2 é o interesse que os professores percebem nos alunos quando discutem conteúdos que fizeram parte da visita ao museu.

Todos os professores responderam afirmativamente quanto a trabalhar conteúdos antes da visita, destacando estes: a vida e as lutas de San Martín, a ética cidadã de San Martín, a travessia dos Andes, emancipação latino-americana, povos originários, sociedade argentina antes e hoje, batalhas da Revolução de Maio, processos revolucionários históricos até a libertação, primeiro anos da vida independente, fundação de Buenos Aires, história colonial, criação do vice-reinado do Rio da Prata, invasões inglesas, história do museu e do Parque Lezama, símbolos da Pátria: "Si, se realiza una anticipación de los contenidos que se van a trabajar durante la visita al museo. Se ve vídeos, fotos de enciclopedias, objetos de cerámica por ejemplo".

Sobre a pergunta referente ao pós-visita, importante destacar que, dos 31 professores que responderam aos questionários, somente um não respondeu a essa questão, ao passo que os demais responderam que, no retorno à escola, realizam trabalhos com os temas estudados por meio de: perguntas, fichas, informe descritivo da visita, narração da visita de forma oral e escrita, apresentação em PowerPoint, apresentação em grupos sobre a vida de San Martín e estudo das efemérides.

$\mathrm{Si}$, se realiza una confrontación con las anticipaciones previas que se habían realizado. Se observan fotos de la salida, se realizan dibujos con las artesanías, se escuchan historias de los habitantes de los pueblos originarios, etc.

Sí, seguimos trabajando con los temas de lo currículo en base a lo observado y vivenciado en el museo.

Comparamos lo leído con los objetos vistos en la visita y retomamos desde ahí. Sí, van a presentar informes, fotografías y láminas donde se registre la visita y su importancia para compartir con el resto del Instituto. 
Se les pide que recuerden lo visto en la visita, se realizan puestas en común y cuestionarios orales y escritos.

Comparemos los conocimientos previos a la visita, con los obtenidos en ella.

Sí. Vamos a trabajar sobre el Sable y el cuarto de San Martín para contar a la comunidad.

Os professores afirmam realizar atividades que sintetizam e revisam a visita, mas somente em duas respostas os alunos realizam trabalho de investigação. Um professor escreveu que os alunos já vêm ao museu com um guia de observação.

Esse breve exercício de escrita dos professores anuncia a crença no museu como espaço de conhecimento, onde os alunos podem ter contato com objetos que os aproximam da história do país. É como se a história dos livros didáticos se materializasse nos objetos expostos que assumem a condição de curiosidades. Algo compreensível, se pensarmos que a História, na qualidade de disciplina, era vista como curiosidade e, por conseguinte, os museus de História carregam também a ideia do passado como algo curioso. Ao mesmo tempo, as respostas apontam a valorização do museu como uma vivência que desperta curiosidade e interesse nos alunos, instigando-os a participar de forma mais efetiva nas aulas.

As respostas indicam que esses professores relacionam o MHN como um lugar que possibilita conhecer a vida e a obra de San Martín, assim como a história da nação. A frase: "levamos os alunos no museu para conhecer nossa história" foi recorrente, dando a ideia, por vezes, de que "a história da nação" é a história de San Martín. A atividade "Búsqueda del tesoro en la Sala Puño y letra y Sala Tesoros" destaca objetos da vida política, militar e privada de San Martín que reafirmam uma narrativa heroica, e não há problematização da memória histórica construída a respeito do "pai da Nação". As respostas formuladas pelos professores no questionário indicam que eles buscam no museu a concretude dos conteúdos estudados. Estariam também esses professores reafirmando o mito? Difícil responder sem compreender melhor suas práticas.

Silvia Finocchio aponta que a memória e a história se mesclaram na escola. Ao largo do século XIX, a História se define como disciplina escolar ao mesmo tempo que o Estado assume a administração da educação e a escola é 
chamada a transmitir os valores da nacionalidade: "la escuela se encargó durante décadas de inducir en el ánimo de niños y jóvenes el 'amor a la Patria"” (Finocchio, 2011, p. 176). E, para isso, um conjunto de práticas escolares foi, década após década, compondo o cenário escolar.

Na Argentina, segundo a autora, a construção desse passado legitimador da nação definia o estudo da história a partir de alguns conteúdos básicos: reinos espanhóis, governos coloniais, invasões estrangeiras, e:

El relato culminaba con los grandes episodios de la independencia y la constitución del Estado nacional, responsable de conducir a la Argentina al destino de una 'gran nación. La historia priorizaba, en consecuencia, al Estado nacional como el principal actor de la realidad argentina, al tiempo que mantenía un criterio de jerarquización social que preservaba la superioridad blanca frente a indígenas y afrodescendentes. (Finocchio, 2007, p. 258)

Tratava-se de uma educação comprometida com a uniformização e a transmissão de valores universais "más allá de la diversidade de los orígenes nacionales, la cultura local o regional, la clase social o la religión”. Nesse contexto, a força pedagógica da escola estava nos ritos cívicos, e ao ensino da história coube inculcar "en esta Argentina de campañas, pueblos, diversidades lingüísticas y culturales, la idea de la nación [...]” (Finocchio, 2007, p. 259).

Diante de um passado ensinado para uniformizar o conhecimento, as mudanças curriculares se faziam difíceis. Durante o século XX ampliaram-se os conteúdos e os planos nacionais, mas o ensino de História permaneceu focalizado no pós-independência. Nos anos ditatoriais imperou uma pedagogia da "neutralidade", freando o estudo de questões polêmicas. Para isso, uma das medidas do governo militar foi "distribuir en todas las escuelas una resolución editada como libro impreso, de ochenta páginas, que se titulaba Subversión en el ámbito educativo (Conozcamos a nuestro enemigo)", convocando os educadores a serem "custodios de nuestra soberanía ideológica" (Finocchio, 2007, p. 265). Nos anos 1990, a reforma educativa provocou mudanças com a introdução do ensino da história recente: ${ }^{3}$

En la transición democrática la enseñanza de la historia acompañó a las políticas de la memoria - antes que a la producción historiográfica -, a través del estudio de los diversos golpes de estado. Al mismo tiempo discutía la relevancia de 
introducir lo controversial en el aula como parte de una pedagogía democrática que ofreciera otra cultura política a las jóvenes generaciones. En esta dirección caminaron diferentes propuestas curriculares, textos escolares y prácticas docentes. (Finocchio, 2007, p. 265)

Hoje, não só a escola argentina, mas a escola do século XXI tem o compromisso de envolver-se nas questões que dizem respeito a este tempo, propondo práticas pedagógicas que possibilitem ao aluno gerar perguntas, questionar certezas, conviver com a diversidade e participar na construção de uma sociedade mais humanizada. Eis o grande desafio para o ensino da História entre a memória e a história: como responder às demandas da sociedade por um ensino mais reflexivo, questionar a memória histórica e, ao mesmo tempo, manter as prerrogativas que legitimam os pertencimentos?

Como diz Manoel Luiz Salgado Guimarães (2009), vivemos em um tempo no qual a História parece convidar mais à emoção do que à reflexão e, neste contexto, não é fácil questionar as memórias que em certo período ganham a cena pública. Antes de tudo, a lembrança carrega consigo um forte recurso de legitimidade e, assim, o desafio do saber histórico, diante das construções mnemônicas, carrega muitas dificuldades e não pode se confundir com ensino de memórias. Talvez, um caminho possível seja o de problematizar a construção da identidade nacional, empreendendo outro projeto de memória, identidade e cidadania que incorpore diferentes grupos. A Sala dos Povos Originários, inaugurada em 2015 no MHN, é, de certa maneira, um começo para pensar esse projeto.

Resta pensar no questionamento indicado no início deste texto: até que ponto a proposta do museu está em consonância com o momento educacional da Argentina, que aponta para o estudo da história recente e a educação em direitos humanos, ou seja, o propósito de pensar o passado tramado no presente?

Gonzalez (2012a, p. 7), discutindo sobre o ensino da história recente na escola Argentina, questiona: Na mesma linha de discussão, Amézola (2011, p. 25) indica que, historicamente, a escola se ocupou do estudo do passado glorioso da pátria, ensinando com o exemplo dos heróis, até que "recibió el mandato de tratar la dictadura, lo que invirtió dramáticamente ese modelo: desde entonces hay que recordar las acciones miserables y despiadadas de los militares 
para aprender a no repetir ese pasado vergonzoso". Como um museu que trata da história nacional se insere no debate da promoção dos direitos humanos? $\mathrm{Ou}$, perguntando de outra maneira, a educação em direitos humanos tem o compromisso com a reflexão sobre os fatos fundadores, que são, por excelência, violentos? Como problematizar a violência das guerras de independência, no contexto de uma educação para os direitos humanos? Ou, ainda, como trabalhar as guerras de independência de forma a não legitimar uma violência do passado mais distante? Pensar isso seria um anacronismo que aproxima violências de tempos distintos? Ou, os sentidos da violência se ressignificam no tempo e permanecem na estrutura da sociedade? E, mesmo cientes de que o mito gera legitimidade, a questão seria saber se devemos continuar reforçando essa identificação ou se é exatamente neste espaço, a escola, que a educação em museus de história pode ser reinventada. Eis o que temos para pensar!

\section{SAlas, aUlas E OUTRAS COISAS MAIS...}

Atualmente os debates sobre o papel educativo do museu afirmam que o objetivo não é mais a celebração de personagens ou a classificação enciclopédica da natureza, e sim a reflexão crítica. Se antes os objetos eram contemplados, agora necessitam ser interpretados, ou corremos o risco de buscar o passado como consolo para um presente pouco atraente. Nos passos de Italo Calvino, pensar sobre o passado, imaginá-lo, conhecê-lo e escrevê-lo talvez nos ajude a ver melhor o nosso presente. Ou o museu constrói um projeto para ser fórum, ou continuará como local para ver o que passou.

Para assumir seu papel educativo, o museu necessita ser o espaço onde os objetos são expostos para compor argumentos críticos. Mas só isso não basta. A mediação é importante e promove a interação dos alunos com os objetos ou as obras, contribuindo com o desenvolvimento de uma educação envolvida com a percepção do mundo. Francisco Regis Lopes Ramos (2004) diz que, se aprendemos a ler palavras, é preciso exercitar o ato de ler objetos, de observar a história que há na materialidade das coisas. Além de interpretar histórias por intermédio dos livros, é possível estudá-la por meio de objetos.

Raimundo Cuesta Fernández (2007, p. 105), ao discutir os deveres da memória na educação, insiste na importância da desescolarização das aprendizagens, que "no significa otra cosa que su deslocalización en múltiples 
lugares que rompan la exclusividad del aula”. Embora ele esteja falando da remodelação do espaço escolar, tornando possível romper as assimetrias de poder entre aluno e professor e retirando os alunos dos contextos tradicionais de aprendizagem, tal assertiva vale muito para pensar a relação museu-escola: aulas sem porta e sem paredes com o propósito de que a oferta educativa da cidade integre as atividades escolares; as relações mudam quando mudam os espaços e os tempos de ensinar e aprender; o currículo da história tem muitas aproximações com o patrimônio cultural (consagrado ou não), e o acesso ao patrimônio público é direito de todos.

A relação que se estabelece entre museu e escola na atualidade é a de aprender com e em contato com os objetos. Portanto, o museu não é somente espaço para os alunos menores, e sim para os jovens que necessitam ser, também, pensados como público privilegiado nas propostas dos museus. Das aulas para as salas, o estudante interage com um espaço que é distinto do espaço da escola, compartilha com outras pessoas momentos vinculados à memória, à história e ao tempo e, com essa experiência, formula perguntas para investigar na escola ou, mais do que tudo, para pensar o mundo, a vida, as relações...

Cabe destacar também que as respostas dos professores aos questionários contrariam o que tenho constatado em diferentes eventos de educação, sobre museus e patrimônio, dos quais participei em Buenos Aires e no Rio Grande do Sul: "os professores não preparam os alunos para a visita no museu"; "não valorizam o que o museu oferece"; "depois da visita, nas escolas nada acontece"; "os alunos não fazem o que pensamos que deveriam fazer"; "o professor não relaciona a atividade do museu com os conteúdos"; "trazem os alunos ao museu para passeio".

Importante questionar até que ponto tais críticas contribuem para uma aproximação mais criativa entre museu e escola, considerando o percurso histórico dessas duas instituições, até então fechadas em si mesmas. Nos museus, a transmissão cultural para um público mais amplo foi a que demorou mais tempo para se constituir e sintetiza três problemas, segundo Dujovne (1995): o que transmitir, a quem, de que maneira. Nas escolas, aprender era memorizar "lições" em um espaço fechado por um tempo determinado. Portanto, aprender na e com a cidade, usufruindo de seus espaços, lendo suas diferentes camadas de tempo e, com isso, descobrir, inventar e formular hipóteses, respostas e argumentos, são questões que estão sendo construídas. Assim, quero crer na 
potência da relação entre museu e escola em aproximações sucessivas e, por extensão, no ensino de história como espaço do novo, do velho, do homogêneo, do diverso...

Por fim, gostaria de dizer do quanto pode ser promissora para a escola a aproximação mais íntima com o museu, para além da mera visita. Certamente também o museu ganha com essa aproximação. Mas, como educadora, falo principalmente da escola! E enfatizo que, para além da retórica que anuncia o fim da escola com estruturas engessadas, avaliações objetivas e conteúdos descontextualizados, prefiro pensar na escola como espaço de "ilusão fecunda" (Sposito, 1993), pois os sonhos e os projetos são tecidos nesse dia a dia da fadiga, do cansaço e da chatice. Não há conclusões definitivas: a escola é espaço de ambivalências. Eis a potência da educação!

\section{REFERÊNCIAS}

AMÉZOLA, Gonzalo de. Historia enseñada e historia investigada: relaciones peligrosas. El tratamiento escolar de la última dictadura militar y la necesidad de una actualización académica en la formación de profesores. PolHis - Revista Bibliográfica del Programa Interuniversitario de Historia Política, Mar del Plata, n. 8, p. 9-26, 2011.

BARBOSA, Ana Mae. Educação em Museus: termos que revelam preconceitos. In: PINHEIRO, Anderson (org.). Diálogo entre arte e público. Recife: Fundação de Cultura Cidade do Recife, 2008. p. 28-32.

BARBUY, Heloísa. Museus, exposições e cidades: cultura visual no século XIX. In: BARBUY, Heloísa (org.). Imagem e produção de conhecimento. São Paulo: Museu Paulista/USP, 2002. p. 66-78.

BOHOSLAVSKY, Ernesto; OLEAGA, Marisa G. de.; LISCIA, María Silvia. Pertenencia y exclusión en el Museo Histórico Nacional de Buenos Aires y el Museo de Trelew en tiempos del Bicentenario. Revista Pilquen, Sección Ciencias Sociales, año XII, n. 13, 2010. Disponível em: http://revele.uncoma.edu.ar/htdoc/revele/index.php/ Sociales/article/view/1888. Acesso em: 2 set. 2019.

BREFE, Ana Cláudia Fonseca. O Museu Paulista: Affonso de Taunay e a memória nacional, 1917-1945. São Paulo: Ed. Unesp; Museu Paulista/USP, 2005.

BUENOS AIRES. Decreto Del Intendente Municipal D. Francisco Seeber Designando Una Comisión Honoraria Para Que Proyecte La Organización Del Museo Histórico Y Lo Instale Provisoriamente. Buenos Aires, 1889. 
CARMAN, Carolina. Los orígenes del Museo Histórico Nacional. Buenos Aires: Prometeo, 2013.

DUJOVNE, Marta. Entre musas y musarañas: una visita al museo. Buenos Aires: FCE, 1995.

FERNÁNDEZ, Raimundo Cuesta. Los deberes de la memoria en la educación. Madrid: Octaedro; MEC y CIDE, 2007. (Colección Educación, Historia y Crítica).

FINOCCHIO, Silvia. Los docentes, los saberes y la mutación de la escuela. In: FINOCCHIO, Silvia; ROMERO, Nancy (comp.). Saberes y prácticas escolares. Rosario: HomoSapiens, 2011. p. 175-199.

FINOCCHIO, Silvia. Entradas educativas en los lugares de la memoria. In: LEVÍN, Florencia; FRANCO, Marina. Historia reciente: perspectivas y desafíos para un campo en construcción. Buenos Aires: Paidós, 2007. p. 253-278.

GONZÁLEZ, María Paula. La enseñanza de la historia argentina en la escuela secundaria. Una aproximación a los recortes temáticos de los docentes en torno a la última dictadura. Reseñas de enseñanza de la historia, Córdoba, v. 9, p. 205-236, 2011.

GONZÁLEZ, María Paula. Historia y memoria del pasado reciente en la escuela: una mirada a la propuesta oficial. Quinto Sol, Santa Rosa, La Pampa, Universidad Nacional de La Pampa, v. 2, n. 16, p. 1-22, 2012a.

GONZÁLEZ, María Paula. Saberes y prácticas docentes en historia: usos y lecturas del Nunca Más. Revista Escuela de Historia, Salta, v. 10, p. 225-246, 2012b.

GUIMARÃES, Manoel Luiz Salgado. Escrita da História e Ensino da História: tensões e paradoxos. In: ROCHA, Helenice; MAGALHÃES, Marcelo; GONTIJO, Rebeca (org.). A escrita da História escolar: memória e historiografia. Rio de Janeiro: Ed. FGV, 2009. p. 35-50.

MENESES, Ulpiano T. Bezerra de. Do teatro da memória ao laboratório da História: a exposição museológica e o conhecimento histórico. Anais do Museu Paulista, São Paulo, v. 2, p. 9-42, jan./dez. 1994.

MUSEO HISTÓRICO NACIONAL. Patrimonio y Museos. Secretaría de Cultura, Presidencia de la Nación. Buenos Aires, 2019. Disponível em: http://www.cultura. gov.ar/direcciones/?info=organismo\&id=14\&idd=5. Acesso em: 1 set. 2019.

RAMOS, Francisco Regis Lopes. A danação do objeto: o museu no ensino de História. Chapecó: Argos, 2004.

SPOSITO, Marilia Pontes. A Ilusão Fecunda: a luta por educação nos movimentos populares. São Paulo: Hucitec: Edusp, 1993. 


\section{NOTAS}

${ }^{1}$ Ronda Cultural é um circuito gratuito em Museus e Espaços Culturais de Buenos Aires. A bordo de miniônibus, com guias especializados, pode-se conhecer parte do patrimônio da cidade. Há percurso definido para público em geral, adultos, escolas e a Ronda Inclusiva. Inscrições e mais informações em: http://ronda.igualdadcultural.gob.ar/que-es-ronda/.

${ }^{2}$ As falas dos(as) professores(as) foram traduzidas do espanhol.

${ }^{3}$ Para aprofundar a reflexão sobre o ensino da história recente na Argentina, ver González (2011; 2012a; 2012b).

Artigo recebido em 2 de setembro de 2019. Aprovado em 20 de novembro de 2019. 